\begin{tabular}{|c|c|c|}
\hline \multirow{3}{*}{$\begin{array}{r}\text { Case Reports in } \\
\text { Gastroenterology }\end{array}$} & \multirow{2}{*}{\multicolumn{2}{|c|}{ Case Rep Gastroenterol 2014;8:44-50 }} \\
\hline & & \\
\hline & $\begin{array}{l}\text { DOI: 10.1159/000358554 } \\
\text { Published online: January 25, } 2014\end{array}$ & $\begin{array}{l}\text { (c) } 2014 \text { S. Karger AG, Basel } \\
\text { 1662-0631/14/0081-0044\$39.50/0 } \\
\text { www.karger.com/crg }\end{array}$ \\
\hline & \multicolumn{2}{|c|}{$\begin{array}{l}\text { This is an Open Access article licensed under the terms of the Creative Commons } \\
\text { Attribution-NonCommercial } 3.0 \text { Unported license (CC BY-NC) (www.karger.com/OA } \\
\text { license), applicable to the online version of the article only. Distribution permitted for non } \\
\text { commercial purposes only. }\end{array}$} \\
\hline
\end{tabular}

\title{
Suspected de novo Hepatitis B in a Patient Receiving Anti-Tumor Necrosis Factor Alpha Therapy for the Treatment of Crohn's Disease
}

\author{
Tetsuya Ishida Hideyasu Nagamatsu Tetsuya Ueo Ryoichi Narita \\ Ken Takahashi Masaki Urabe Yuka Yanai Kazumi Togo
}

Department of Gastroenterology, Oita Red Cross Hospital, Oita, Japan

\section{Key Words}

De novo hepatitis B - Anti-tumor necrosis factor $\alpha$ therapy · Crohn's disease

\begin{abstract}
We report a 45-year-old female patient who developed acute hepatic disorder during antitumor necrosis factor $\alpha$ therapy for the treatment of Crohn's disease (CD). She was diagnosed as colonic CD and placed on infliximab (IFX). She was negative for hepatitis B surface antigen at the initiation of IFX therapy, but developed acute hepatitis after the 30th administration of IFX 4 years and 1 month after the first administration. She was suspected to have had occult hepatitis B virus infection before IFX therapy, and de novo hepatitis B was considered the most likely diagnosis. Hepatitis subsided after discontinuation of anti-tumor necrosis factor $\alpha$ therapy and initiation of treatment with entecavir. She started to receive adalimumab to prevent relapse of $C D$. She has continued maintenance therapy with entecavir and adalimumab and has since been asymptomatic. As de novo hepatitis B may be fatal, virological testing for hepatitis $B$ is essential for patients who are being considered for treatment that may weaken the immune system.

(C) 2014 S. Karger AG, Basel
\end{abstract}

\section{Introduction}

Biologic agents and immunomodulators have become essential components in the treatment of inflammatory bowel disease (IBD). Especially in the treatment of Crohn's disease (CD), anti-tumor necrosis factor $\alpha$ (anti-TNF $\alpha$ ) antibodies such as infliximab (IFX) and adalimumab (ADA) are expected to improve the clinical course [1-3]. Since biologic

Tetsuya Ishida

Department of Gastroenterology, Oita Red Cross Hospital

3-2-37 Chiyo-machi, Oita 870-0033 (Japan)

E-Mail tetsi@oita-u.ac.jp 
Ishida et al.: Suspected de novo Hepatitis B in a Patient Receiving Anti-Tumor Necrosis Factor Alpha Therapy for the Treatment of Crohn's Disease

agents such as IFX and ADA exert their effects promptly and may be used for remission induction and maintenance in $\mathrm{CD}$, an increasingly large number of patients are being treated with these drugs.

On the other hand, there have been reported cases of severe liver dysfunction caused by hepatitis B virus (HBV) reactivation in patients receiving rituximab for the treatment of malignant lymphoma $[4,5]$. Since reactivation of HBV may lead to a fatal outcome, it is very important to prevent HBV reactivation in the clinical setting. While HBV reactivation during biologic therapy has been reported among healthy carriers of hepatitis B surface antigen (HBsAg) with normal hepatic function, occurrence of HBV reactivation among patients with occult HBV infection is relatively rare [6, 7].

We report a female patient with CD who developed hepatic disorder probably due to de novo hepatitis B during IFX therapy. Since she discontinued anti-TNF $\alpha$ therapy and started to receive entecavir (ETV), severe liver dysfunction could be avoided. After negative HBV DNA tests had been confirmed, she started to receive ADA. No recurrence of hepatitis B or CD has been observed since then. Patients with IBD must be tested for HBsAg, anti-hepatitis B surface antibody (anti-HBsAb) and anti-hepatitis B core antibody (anti-HBcAb) prior to the introduction of immunomodulation therapy.

\section{Case Report}

A 41-year-old woman had abdominal pain, diarrhea and fever in July 2006. Because of persistent symptoms, she was hospitalized in August 2006. A cobblestone-like appearance was seen in the sigmoid colon upon colonoscopy. On the basis of the results of detailed examination, she was diagnosed as having colonic CD. Since she had severe CD with a Crohn's disease activity index (CDAI) of 373 and needed prompt and effective treatment, treatment with IFX at $5 \mathrm{mg} / \mathrm{kg}$ and 6-mercaptopurine (6-MP) at $30 \mathrm{mg} /$ day was initiated in September 2006. Laboratory findings at the initiation of treatment included an aspartate transaminase (AST) level of $22 \mathrm{IU} / \mathrm{l}$, an alanine transaminase (ALT) level of $22 \mathrm{IU} / \mathrm{l}$ and negative HBsAg. She was not tested for anti-HBsAb and anti-HBcAb. At week 10 of IFX therapy, symptoms were alleviated (CDAI: 56), and remission was successfully induced. IFX was administered at weeks 0,2 and 6 and every 8 weeks thereafter, and remission was successfully maintained. Colonoscopy about 1 year after the initiation of treatment revealed colonic mucosal healing with scarring. However, about 1 year after the initiation of IFX therapy, she began to experience delayed-onset hypersensitivity reactions to IFX such as fever and joint pain. We thus considered switching biologic therapy from IFX to ADA. On October 8, 2010, 4 years and 1 month after the first administration of IFX, the 30th and final administration of IFX was given, and her hepatic function was normal (AST 16 IU/l, ALT $21 \mathrm{IU} / \mathrm{l}$ ). On December 12, 2010, hepatic function test immediately before the first administration of ADA revealed mild hepatic dysfunction (AST 61 IU/l, ALT 54 IU/l). Since no abnormal hepatic function had been found before and the cause was unknown, she received $160 \mathrm{mg}$ of ADA on that day and was followed up thereafter. On December 17, 2010, although hepatic enzyme levels were still high, she received $80 \mathrm{mg}$ of ADA.

On January 4, 2011, since she felt generalized malaise with an AST of $322 \mathrm{IU} / \mathrm{l}$ and an ALT of $527 \mathrm{IU} / \mathrm{l}$, she was hospitalized for detailed examination and treatment (fig. 1). Examinations revealed HBsAg of $250 \mathrm{IU} / \mathrm{ml}$ and $\mathrm{HBV}$ DNA of $>9.0 \log$ copies $/ \mathrm{ml}$. HBV genotype was type $\mathrm{C}$, and anti-hepatitis $\mathrm{C}$ virus antibody (anti-HCVAb) was negative (table 1). Virological testing of a sample obtained from her husband revealed negative results for HBsAg and anti-HBcAb and no detection of HBV DNA. Sexual transmission of 
Ishida et al.: Suspected de novo Hepatitis B in a Patient Receiving Anti-Tumor Necrosis Factor Alpha Therapy for the Treatment of Crohn's Disease

HBV from her husband and others was ruled out. Abdominal echo and computed tomography examination showed no evidence of chronic hepatic disorder. Liver biopsy revealed mild fibrosis (A2/F1). These findings supported the presence of hepatic disorder due to HBV. Although no data on HBV DNA and anti-HBcAb before onset were available, her clinical course suggested de novo hepatitis $B$ due to reactivation of HBV related to the treatment with IFX and 6-MP.

On January 5, 2011, antiviral treatment with ETV at $0.5 \mathrm{mg} /$ day was initiated. Treatment with ADA was suspended after the first two administrations, but treatment with 6-MP was continued. Ten sessions of granulocytapheresis were conducted to maintain remission of CD. AST and ALT levels peaked at $440 \mathrm{IU} / \mathrm{l}$ and $624 \mathrm{IU} / \mathrm{l}$, respectively, on January 14, 2011, and then decreased gradually over time. On March 29, 2011, hepatic function returned to normal (AST $30 \mathrm{IU} / \mathrm{l}$, ALT $24 \mathrm{IU} / \mathrm{l}$ ). Since negative HBV DNA results were obtained in June 2011, treatment with ADA was reintroduced (fig. 2). Since then she has continued treatment with ETV and has maintained normal levels of AST, ALT and HBV DNA without recurrence of hepatitis B. 10 months after treatment with ETV, her anti-HBsAb turned positive. She has also continued ADA and has maintained mucosal integrity and clinical remission without gastrointestinal symptoms.

\section{Discussion}

Anti-TNF $\alpha$ therapy has a central role in the treatment of CD. It is well known that anti$\mathrm{TNF} \alpha$ therapy is superior to conventional treatment in terms of rates of hospitalization, surgery and repeated surgery, among other outcome measures [8]. With anti-TNF $\alpha$ therapy, our patient maintained clinical remission and mucosal healing and achieved 'sustained deep remission'. Since it is known that rates of rehospitalization and repeated surgery are low in patients with deep remission and better prognosis is expected [9], our patient is expected to have a favorable prognosis. On the basis of the favorable results biologics, especially anti-TNF $\alpha$ antibody therapy, have become an essential component of the treatment of IBD.

On the other hand, TNF plays an important role in eliminating HBV by inhibiting the replication of HBV and promoting HBV-specific T cell response. Thus, the risk of HBV reactivation may increase in patients receiving immunomodulatory agents, including antiTNF $\alpha$ antibody drugs. The most significant and well-documented adverse event during biologic therapy is acute hepatic failure related to rituximab.

Conventionally, if HBsAg is negative and anti-HBcAb and/or anti-HBsAb is positive, hepatitis $B$ is considered cured in the clinical setting, and such patients are referred to as 'occult HBV' carriers. However, hepatitis due to HBV reactivation (de novo hepatitis B) in occult HBV carriers has been reported. Hepatitis due to HBV reactivation can frequently become serious, and the mortality rate has been reported to be as high as $20 \%$ in one reference. Appropriate measures to prevent HBV reactivation are therefore essential.

Yeo and Johnson [10] reported that HBV reactivation during biologic therapy may frequently develop among healthy carriers of $\mathrm{HBsAg}$, but such events are relatively rare among occult HBV carriers. In fact, the rate of HBV reactivation among patients receiving immunomodulation therapy without measures to prevent it has been reported to be $20-50 \%$ in healthy HBV carriers and 5\% in occult HBV carriers [7, 11]. Manzano-Alonso and CastellanoTortajada [12] analyzed 21 reported cases of HBV reactivation associated with IFX therapy, and reported that HBV infection at baseline was inactive state in 15 cases, chronic active hepatitis in 4 cases and occult HBV in 1 case. In the patient with occult HBV, acute hepatitis B 
Ishida et al.: Suspected de novo Hepatitis B in a Patient Receiving Anti-Tumor Necrosis Factor Alpha Therapy for the Treatment of Crohn's Disease

developed after the sixth administration of IFX for the treatment of CD and was successfully treated with lamivudine [13]. The patient was also receiving prednisone at the onset of HBV reactivation.

Our patient is the second reported case of HBV reactivation in a previously HBsAgnegative patient (occult HBV carrier) with CD treated with IFX. She was diagnosed with CD in 2006, at that time only HBsAg was tested to screen for hepatitis B, and the risk of biologicinduced HBV reactivation was not yet recognized. Since the patient's husband had negative anti-HBsAb, negative HBcAb and no detection of HBV DNA, transmission from her husband and others was ruled out, and she was suspected to have had occult HBV infection and developed IFX-induced HBV reactivation.

Many drugs used for the treatment of IBD are also used to treat rheumatoid arthritis and collagen diseases. In a survey of HBV reactivation due to the use of biologics and immunomodulators in patients with rheumatoid arthritis and other collagen diseases, the risk of HBV reactivation (detection of HBV DNA) by IFX among patients not receiving antiviral therapy was $6-8 \%$, which is lower than for rituximab but higher than for conventional chemotherapy.

In general, it is believed that in patients with occult HBV infection, symptomatic hepatitis develops a few months after detection of HBV DNA in the blood during chemotherapy [14]. When antiviral therapy is performed during this period, severe hepatitis may be prevented. Although we could not conduct appropriate preventive measures during this period in our patient, we could save her life by starting treatment with a nucleoside analogue before severe hepatitis developed.

After resolution of hepatitis, ADA was reintroduced to maintain deep remission of CD while antiviral therapy was continued. It is expected that HBV reactivation in patients positive for HBsAg may be prevented if they receive antiviral therapy before the initiation of biologic or immunomodulation therapy [10]. During the 2.5 years after the reintroduction of ADA, our patient has not experienced HBV reactivation, CD flare or treatment-limiting adverse drug reactions.

In conclusion, a patient with $\mathrm{CD}$ and occult $\mathrm{HBV}$ infection experienced $\mathrm{HBV}$ reactivation 4 years and 1 month after the initiation of IFX therapy. Since reactivation of previously occult hepatitis B may occur after prolonged immunomodulation therapy, patients should be monitored carefully. As with patients with collagen disease, patients with IBD must be tested for HBsAg, anti-HBsAb and anti-HBcAb before starting immunosuppressive treatment.

\section{Disclosure Statement}

The authors declare that they have no competing interests.

\section{References}

1 Rutgeerts P, Diamond RH, Bala M, Olson A, Lichtenstein GR, Bao W, Patel K, Wolf DC, Safdi M, Colombel JF, Lashner B, Hanauer SB: Scheduled maintenance treatment with infliximab is superior to episodic treatment for the healing of mucosal ulceration associated with Crohn's disease. Gastrointest Endosc 2006;63:433442.

2 Minderhoud IM, Samsom M, Oldenburg B: What predicts mucosal inflammation in Crohn's disease patients? Inflamm Bowel Dis 2007;13:1567-1572. 


\begin{tabular}{l|l}
\hline Case Rep Gastroenterol 2014;8:44-50 \\
\hline DOI: 10.1159/000358554 & $\begin{array}{l}\text { @ 2014 S. Karger AG, Basel } \\
\text { www.karger.com/crg }\end{array}$ \\
\hline
\end{tabular}

Ishida et al.: Suspected de novo Hepatitis B in a Patient Receiving Anti-Tumor Necrosis Factor Alpha Therapy for the Treatment of Crohn's Disease

3 Baert F, Moortgat L, Van Assche G, Caenepeel P, Vergauwe P, De Vos M, Stokkers P, Hommes D, Rutgeerts P, Vermeire S, D’Haens G; Belgian Inflammatory Bowel Disease Research Group; North-Holland Gut Club: Mucosal healing predicts sustained clinical remission in patients with early-stage Crohn's disease. Gastroenterology 2010;138:463-468.

4 Dervite I, Hober D, Morel P: Acute hepatitis B in a patient with antibodies to hepatitis B surface antigen who was receiving rituximab. N Engl J Med 2001;344:68-69.

5 Lok ASF, Liang RHS, Chiu EKW, Wong KL, Chan TK, Todd D: Reactivation of hepatitis B virus replication in patients receiving cytotoxic therapy. Gastroenterology 1991;100:182-188.

-6 Kusumoto S, Tanaka Y, Mizokami M, Ueda R: Reactivation of hepatitis B virus following systemic chemotherapy for malignant lymphoma. Int J Hematol 2009;90:13-23.

7 Loomba R, Rowley A, Wesley R, Liang TJ, Hoofnagle JH, Pucino F, Csako G: Systematic review: the effect of preventive lamivudine on hepatitis B reactivation during chemotherapy. Ann Intern Med 2008;148: 519-528.

-8 Feagan BG, Panaccione R, Sandborn WJ, D’Haens GR, Schreiber S, Rutgeerts PJ, Loftus EV Jr, Lomax KG, Yu $\mathrm{AP}, \mathrm{Wu}$ EQ, Chao J, Mulani P: Effects of adalimumab therapy on incidence of hospitalization and surgery in Crohn's disease: results from the CHARM study. Gastroenterology 2008;135:1493-1499.

$\checkmark$ Colombel JF, Louis E, Peyrin-Biroulet L, Sandborn WJ, Panaccione R: Deep remission: a new concept? Dig Dis 2012;30:107-111.

10 Yeo W, Johnson PJ: Diagnosis, prevention and management of hepatitis B virus reactivation during anticancer therapy. Hepatology 2006;43:209-220.

11 Loras C, Gisbert JP, Minguez M, Merino O, Bujanda L, Saro C, Domenech E, Barrio J, Andreu M, Ordas I, Vida L, Bastida G, Gonzalez-Huix F, Piqueras M, Ginard D, Calvet X, Gutierrez A, Abad A, Torres M, Panes J, Chaparro M, Pascual I, Rodriguez-Carballeira M, Fernandez-Banares F, Viver JM, Esteve M: Liver dysfunction related to hepatitis $\mathrm{B}$ and $\mathrm{C}$ in patients with inflammatory bowel disease treated with immunosuppressive therapy. Gut 2010;59:1340-1346.

12 Manzano-Alonso ML, Castellano-Tortajada G: Reactivation of hepatitis B virus infection after cytotoxic chemotherapy or immunosuppressive therapy. World J Gastroenterol 2011;17:1531-1537.

13 Madonia S, Orlando A, Scimeca D, Olivo M, Rossi F, Cottone M: Occult hepatitis B and infliximab-induced HBV reactivation. Inflamm Bowel Dis 2007;13:508-509.

$\checkmark 14$ Hui CK, Cheung WWW, Zhang HY, Au WY, Yueng YH, Leung AYH, Leung N, Luk JM, Lie AKW, Kwong YL, Liang R, Lau GKK: Kinetics and risk of de novo hepatitis B infection in HBsAg-negative patients undergoing cytotoxic chemotherapy. Gastroenterology 2006;131:59-68. 
Table 1. Laboratory findings on admission

\begin{tabular}{|c|c|c|c|}
\hline \multicolumn{2}{|c|}{ Peripheral blood } & \multicolumn{2}{|l|}{ Coagulation } \\
\hline WBC & $5,200 / \mu \mathrm{l}$ & PT & $70.5 \%$ \\
\hline Neutro & $56.8 \%$ & & \\
\hline Eos & $2.7 \%$ & Serology & \\
\hline Baso & $0.4 \%$ & CRP & $0.02 \mathrm{mg} / \mathrm{dl}$ \\
\hline Lympho & $31.8 \%$ & $\operatorname{IgG}$ & $1,480 \mathrm{mg} / \mathrm{dl}$ \\
\hline $\mathrm{RBC}$ & $412 \times 10^{4} / \mu \mathrm{l}$ & $\operatorname{Ig} A$ & 109 mg/dl \\
\hline $\mathrm{Hb}$ & $12.3 \mathrm{~g} / \mathrm{dl}$ & $\operatorname{IgM}$ & $290 \mathrm{mg} / \mathrm{dl}$ \\
\hline Plt & $25.2 \times 10^{4} / \mu \mathrm{l}$ & ANA & $\times 40$ \\
\hline \multicolumn{2}{|c|}{ Blood chemistry } & \multicolumn{2}{|l|}{ Virus marker } \\
\hline $\mathrm{TP}$ & $8.2 \mathrm{~g} / \mathrm{dl}$ & HA-IgM & $(-)$ \\
\hline Alb & $4.1 \mathrm{~g} / \mathrm{dl}$ & HCVAb & $(-)$ \\
\hline T-Bil & $0.6 \mathrm{mg} / \mathrm{dl}$ & HCV RNA & $(-)$ \\
\hline D-Bil & $0.2 \mathrm{mg} / \mathrm{dl}$ & EBV-IgM & $<10$ \\
\hline AST & 322 IU/l & EBV-IgG & $\times 160$ \\
\hline ALT & $527 \mathrm{IU} / \mathrm{l}$ & EBV-EBNA & $\times 80$ \\
\hline LDH & $319 \mathrm{IU} / \mathrm{l}$ & CMV-IgM & $(-)$ \\
\hline ALP & $254 \mathrm{IU} / \mathrm{l}$ & CMV-IgG & $(+)$ \\
\hline$\gamma$-GTP & 76 IU/l & HBsAg & $250 \mathrm{IU} / \mathrm{ml}$ \\
\hline $\mathrm{ChE}$ & 337 IU/l & HBsAb & $(-)$ \\
\hline $\mathrm{TG}$ & $66 \mathrm{mg} / \mathrm{dl}$ & HbEAg & $1,485 \mathrm{~S} / \mathrm{CO}$ \\
\hline T-cho & $161 \mathrm{mg} / \mathrm{dl}$ & $\mathrm{HBeAb}$ & $0 \%$ \\
\hline BUN & $18 \mathrm{mg} / \mathrm{dl}$ & HBV DNA & $>9.0 \log$ copies $/ \mathrm{m}$ \\
\hline Cre & $0.6 \mathrm{mg} / \mathrm{dl}$ & HBV genotype & type $\mathrm{C}$ \\
\hline $\mathrm{Na}$ & $139 \mathrm{mEq} / \mathrm{l}$ & & \\
\hline K & $4.2 \mathrm{mEq} / \mathrm{l}$ & & \\
\hline $\mathrm{Cl}$ & $104 \mathrm{mEq} / \mathrm{l}$ & & \\
\hline Ferritin & $21 \mathrm{ng} / \mathrm{ml}$ & & \\
\hline
\end{tabular}

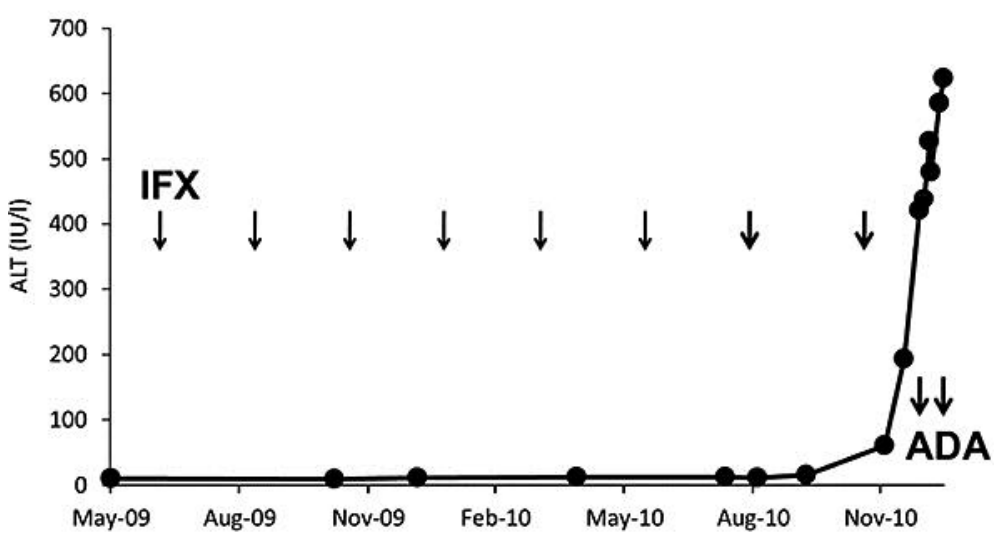

Fig. 1. Clinical course of the present case before HBV reactivation. 


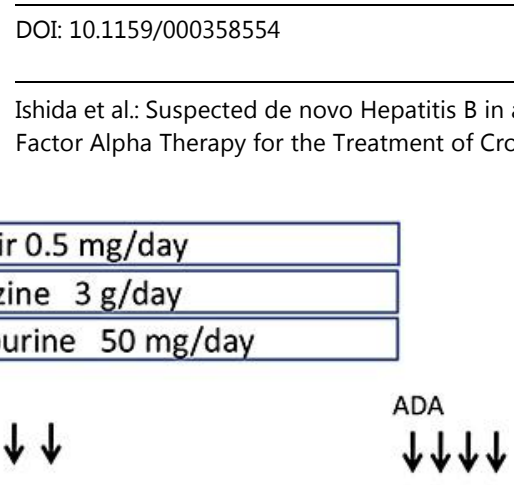

(C) 2014 S. Karger AG, Basel

www.karger.com/crg

Ishida et al.: Suspected de novo Hepatitis B in a Patient Receiving Anti-Tumor Necrosis Factor Alpha Therapy for the Treatment of Crohn's Disease

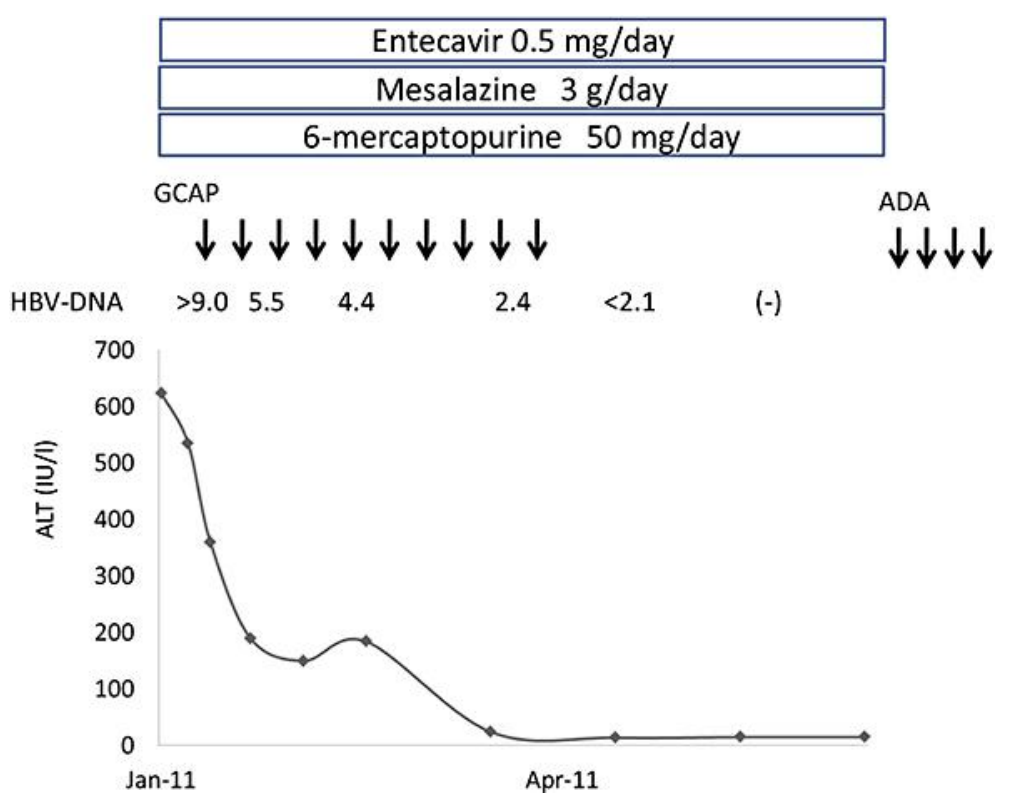

Fig. 2. Clinical course of the present case after anti-virus therapy started. GCAP = Granulocytapheresis. 